\title{
Prevalence of Hepatitis C among Lichen Planus patients
}

\author{
Sharma $\mathbf{R}^{1}$, Paudel $\mathbf{S}^{1}$ \\ ${ }^{1}$ Department of Dermatology and Venereology, Civil Services Hospital, Kathmandu, Nepal
}

\begin{abstract}
Introduction: The association between hepatitis C virus (HCV) infection and lichen planus (LP) has been studied widely. Extrahepatic manifestations including lichen planus are common among patients infected with HCV. The prevalence of HCV among lichen planus (LP) seems to vary geographically.

Objective: This study was carried out to determine whether an association exists between LP and HCV infection.

Materials and Methods: A total of 68 lichen planus (LP) patients identified clinically and histopathologically were screened for anti-HCV from blood samples.

Results: Among the 68 patients of LP only 2 (2.94\%) female patients had HCV infection.

Conclusion: This study reveals very few patients of lichen planus being infected with HCV which is in line with a similar study done earlier in Kathmandu. Thus due to limited evidence to support an association between HCV and LP routine $\mathrm{HCV}$ screening is not recommended at this geographic location.
\end{abstract}

Key words: Hepatitis C; Lichen Planus; Nepal

\section{Introduction}

ichen planus (LP) is a T-cell-mediated chronic inflammatory skin disease with unknown etiology. It can affect oral mucosa, genitalia, the skin, nails, hair follicles, esophagus, urinary tract, nasal mucosa, larynx and rarely the eyes. ${ }^{1}$ Some studies have revealed an increased prevalence of chronic liver diseases in patients with LP. ${ }^{2}$ Divano et $\mathrm{al}^{3}$ found anti hepatitis $C$ virus antibody in $50 \%$ of patients with LP in their study. Several other studies have conflicting results with some showing associations and others refuting such an association of LP with Hepatitis C virus. ${ }^{2-6}$ Because of these observations anti HCV antibody and its association with LP has increasingly being studied.

This study was carried out to determine whether Hepatitis $C$ is highly prevalent among patients of lichen planus so that the silent disease could be diagnosed early if it manifested with the cutaneous marker.

Financial disclosure: None.

Conflict of interest to disclosure: None declared.

\section{Address of Correspondence}

Dr. Rabindra Sharma

Registrar

Department of Dermatology and Venereology

Civil Services Hospital, Kathmandu, Nepal

E-mail:sharmarabindra@rocketmail.com

\section{Material and Methods}

This is a cross-sectional study carried out in a tertiary care hospital in Kathmandu validated by the institutional review and ethical board. All cases of lichen planus who attended to the outpatient department of the hospital between January 2017 to july 2018 were included in the study. The morphologic type of lichen planus, distribution and comorbidities if any were recorded. Patients with a history of blood transfusion, IV drug abuse, liver disease, lichenoid drug eruption, dental amalgam and alcohol abuse were excluded from the study. Blood samples were taken from all 68 patients for HCV antibodies detection. The kit used was Hepatitis C virus encoded antigens NS3, NS4, NS5. Thus a fourth generation HCV TRI-DOT test

Submitted: $21^{\text {st }}$ November 2019

Accepted: $27^{\text {th }}$ December 2019

Published: $7^{\text {th }}$ October 2020

How to cite this article

Sharma R, Paudel S. Prevalence of Hepatitis $\mathrm{C}$ among lichen planus patients. Nepal Journal of Dermatology Venereology and Leprology 2020;18(1):15-7. https://doi.org/10.3126/njdvl. v18i1.30351.

\section{(c) (7)}

Licensed under CC BY 4.0 International License which permits use, distribution and reproduction in any medium, provided the original work is properly cited. 
was done. Baseline laboratory investigations including liver function tests were done in all cases. Data were entered in excel and analysis was done using SPSS 22.

\section{Results}

A total of 68 clinically and histologically confirmed cases of lichen planus (LP) including both sexes were studied. There were 37 females (54.41\%), 31 males (45.59\%). Mean age of the study population was 43.63 years. Mean duration of the disease was 5.57 months, 62 cases (91.1\%) being in the range of $0-12$ months. Among them, 22 cases (32.35\%) were in the third and fourth decades. Only 30 patients (44.12\%) had oral lesions (Table 1). Only two patients were antiHCV antibody positive among all the 68 patients of lichen planus. Both the HCV infected lichen planus patients were female and thus none of the male LP patients were infected with HCV. Out of those, one had hypertrophic lesions of lichen planus and the other had oral erosive lesions with desquamative gingivitis. Liver function tests were normal in both the cases.

Table 1: Morphological distribution of Lichen Planus (LP).

\begin{tabular}{|c|c|c|}
\hline Types of Lichen Planus & $\begin{array}{c}\text { No. of } \\
\text { Cases }\end{array}$ & Percentage(\%) \\
\hline Oral LP + Orocutaneous & 30 & 44.12 \\
\hline Cutaneous only & 36 & 52.94 \\
\hline Genital only & 2 & 2.94 \\
\hline Genitocutaneous & None & 0 \\
\hline
\end{tabular}

\section{Discussion}

Hepatitis C virus (HCV) is a single-stranded RNA virus which has an extremely variable genome with six distinct genotypes and multiple subtypes. Morbidity associated with HCV infection are due to chronic liver diseases as well as various extrahepatic manifestations. ${ }^{4}$ So far, many case control studies have been done implicating or refuting HCV association in LP. Most of the positive studies that have described a high prevalence of hepatitis $C$ virus infection in patients with LP are from Japan and Western countries especially Spain and Italy. ${ }^{5-8}$ Correlation between HCV infection and LP has mostly been reported with the oral form of the disease i.e the oral lichen planus(OLP) and some oral diseases such as Sjögren's syndrome, and sialadenitis. Besides hepatitis C, OLP was found associated with a number of viral infections including Epstein-Barr virus, cytomegalovirus, varicella zoster virus, human herpes virus, human papilloma virus, and human immunodeficiency virus (HIV). However, the most frequent evidence relates to HCV infections..$^{9,10}$ Most of these studies are from Western countries and no such evidence is available from Nepal and the Indian subcontinent. Among the studies conducted in Nepal, Rajouria EA and colleague reported only 5 (41.6\%) patients out of 12 oral LP positive for HCV antibodies but none of their cutaneous form of LP patients showed positive reaction to HCV antibodies whereas Garg VK et al didn't find a correlation between lichen planus and hepatitis $\mathrm{c}$ in another study from Nepal. ${ }^{11,12}$ In all those studies association of HCV antibody in lichen planus was reported to vary geographically from one to another ranging from $4 \%$ to $38 \% .^{13,14}$ Interestingly no correlation was observed between the viral load and HCV genotypes with the likelihood of developing LP in HCV-infected patients in some of the studies. ${ }^{15-17}$ Thus the association of HCV infections and $\mathrm{LP}$ is regional based correlation and non-homogeneity in results from different geographic areas may have several reasons and factors.

However this is simply a hospital based study which may not represent the population as a whole. As LP has been found to be more prevalent among certain genomes of HCV infected population genetic makeup studies are required in a low HCV prevalent country like Nepal. This is not a case controlled study thus chances of bias and error due to confounding factors is possible. Moreover, HCV diagnosis is simply based on kit based AntiHCV antibody test only and no HCV RNA analysis was done.

\section{Conclusion}

Only two cases among the total 68 cases of lichen planus were positive for Hepatitis $C$ antibody. One of the patients was an isolated case of oral without other cutaneous or nail findings clinically whereas the other was an isolated case of cutaneous (morphologically hypertrophic variant) without oral, genital or nail findings of lichen planus. Thus, this study doesn't approve the routine serological testing for HCV among patients with lichen planus although larger hospital as well as population based studies are recommended to make an astute decision. 


\section{References}

1. Sugerman PB, Savage NW, Walsh LJ, Zhao ZZ, Zhou XJ, Khan A, et al. The pathogenesis of oral lichen planus. Crit Rev Oral Biol Med 2002;13(4):350-65. https://doi. org/10.1177/154411130201300405

2. Gandolfo S, Carbone M, CarrozzoM, Gallo V. Lichen planus and hepatitis C virus (HCV) infection. Oral Pathol Med 1994;23:119:1-22. https://doi.org/10.1111/j.1600-0714.1994. tb01098.x

3. Divano MC, Parodi A, Rebora A. Lichen planus, liver-kidney micro-somal (LKM) antibodies and hepatitis C virus antibodies. Dermatology 1992;183:131-3. https://doi.org/10.1159/000247428

4. Carrozzo M, Gandolfo S. Oral diseases possibly associated with hepatitis $C$ virus. Crit Rev Oral Biol Med 2003;14(2):115-27. https://doi. org/10.1177/154411130301400205

5. Nagoo Y, Sato M, Fukuzumi K, et al. High incidence of orallichen planus in an hepatitis $\mathrm{C}$ virus endemic area. Gastroenterology 2000;119: 882-3. https://doi.org/10.1053/gast.2000.17936

6. Van derMeij EH, van der Wal I. Hepatitis C virus and oral lichen planus: a report from the Netherlands. J Oral Pathol Med 2000;29: 225-58. https://doi.org/10.1034/j.16000714.2000.290603.x

7. Dupond AS, Locour JP, LafontC, Ortonne JP. Prevalence of hepatitis $C$ virus in oral erosive lichen. Ann Dermatol Venereol 1998;125: 6768.

8. Criber B, Garnier C, LaustratD, Heid E. lichen planus and hepatitis $C$ virus infection: an epidemiologic study. J Am Acad Dermatol 1994; 31: 1070-2. https://doi.org/10.1016/S01909622(09)80092-3

9. Lodi G, Scully C, Carrozzo M, Griffiths M, Sugerman PB, Thongprasom K. Current controversies in oral lichen planus: report of an international consensus meeting. Part 1.Viral infections and etiopathogenesis.Oral Surg Oral Med Oral Pathol Oral RadiolEndod 2005;100(1):40-51. https:// doi.org/10.1016/j.tripleo.2004.06.077
10. Pellicano R, Palmas F, Leone N, Vanni E, Carrozzo M, Gandolfo $S$, et al. Previous tuberculosis, hepatitis $C$ virus and lichen planus. A report of 10 cases, a causal or casual link? Panminerva Med 2000;42(1):77-81.

11. Rajouria EA, Amatya A, Karn D. Association of Lichen Planus with $\mathrm{HCV}$ and HBV in Nepal. PMJN 2011;11(1):1-4. https://doi.org/10.3126/ojn.v1i1.9359

12. Garg VK, Karki BM, Agrawal S, Agarwalla A, Gupta R. A study from Nepal showing no correlation between lichen planus and hepatitis B and C viruses.J Dermatol 2002;29(7):4113. https://doi.org/10.1111/j.1346-8138.2002. tb00295.x

13. Sanchez-Perez J, De-Castro M, Buezo GF, Fernandez-Herrera J, Borque MJ, García-Díez A. Lichen planus and hepatitis $C$ virus: Prevalence and clinical presentation of patients with LP and HCV infection. Br J Dermatol 1996;134:7159. https://doi.org/10.1111/j.1365-2133.1996. tb06977.x

14. Imhof $M$, Popai $H$, Lee JH, Zeuzem S, Milbradt R. Prevalence of hepatitis $C$ virus, antibodies and evaluation of HCV genotypes in patients with LP. Dermatology 1997;195:1-5. https://doi.org/10.1159/000245675

15. Lodi G, Carrozzo M, Hallett R, D'Amico E, Piattelli A, Teo CG, et al. HCV genotypes in Italian patients with HCV-related oral lichen planus. J Oral Pathol Med 1997;26(8):381-4. https://doi.org/10.1111/j.1600-0714.1997. tb00235.x

16. Nagao $\mathrm{Y}$, Sata $\mathrm{M}$, Itoh $\mathrm{K}$, Tanikawa K, Kameyama T. Quantitative analysis of HCV RNA and genotype in patients with chronic hepatitis C accompanied by oral lichen planus. Eur J Clin Invest 1996;26(6):495-8. https://doi. org/10.1046/j.1365-2362.1996.167314.x

17. Pawlotsky JM, Benchiki H, Pellet C, Duval J, Dhumeaux D, Revuz J, et al. Lichen planus and hepatitis $\mathrm{C}$ virus ( $\mathrm{HCV}$ )-related chronic hepatitis: evaluation of HCV genotypes. $\mathrm{Br} J$ Dermatol 1995;133(4):666-7. https:// doi.org/10.1111/j.1365-2133.1995. tb02734.x 